Berkala Ilmu Perpustakaan dan Informasi, Vol. 14, No. 1, Juni 2018, Hal. 87-94 DOI: $10.22146 /$ bip.17501

ISSN 1693-7740 (Print), ISSN 2477-0361 (Online)

Tersedia online di https://jurnal.ugm.ac.id/bip

\title{
Analisis hubungan prestasi akademik mahasiswa dengan akses sumber informasi
}

\author{
Prijana $^{1}$ dan Andri Yanto ${ }^{1}$ \\ ${ }^{1}$ Fakultas Ilmu Komunikasi, Universitas Padjadjaran \\ Email:prijana@unpad.ac.id
}

Naskah diterima: 29 Desember 2016, direvisi: 2 November 2017, disetujui: 18 April 2018

\begin{abstract}
ABSTRAK
Pendahuluan. Dalam proses membaca, mahasiswa memerlukan berbagai sumber informasi untuk meningkatkan prestasi akademiknya. Penelitian bertujuan untuk menemukan sumber informasi yang memiliki hubungan dengan prestasi akademik mahasiswa dan menjadi rujukan dalam pengembangan sumber informasi yang dapat mendukung peningkatan prestasi akademik mahasiswa.

Metode. Metode penelitian yang digunakan adalah metode eksperimen, dengan $\mathrm{N}=38$. Nilai chi-square dihitung sebesar 11.613, dengan P-value sebesar 0,169, jika $\alpha=0.25, \mathrm{dk}=8$, maka Chi-quadrat tabel $=10.2$, artinya Chiquadrat hitung (11.6) lebih besar daripada Chi-quadrat tabel (10.2). Jika Chi-quadrat hitung lebih besar dari pada Chi-quadrat tabel, maka prestasi akademik mahasiswa memiliki hubungan signifikan dengan akses sumber informasi.

Hasil dan Pembahasan. Hasil penelitian menunjukkan bahwa prestasi akademik mahasiswa memiliki hubungan signifikan dengan akses sumber informasi. Perilaku mahasiswa dengan mengakses sumber informasi multi akses memiliki derajat hubungan moderat dengan prestasi akademik yang dicapai, artinya tidak ada sumber informasi yang dominan yang dipakai mahasiswa dalam rangka meraih prestasi akademik.

Kesimpulan. Dalam penelitian ini adalah mahasiswa lebih memilih untuk mengakses sumber informasi multi akses, yang menghasilkan sebaran nilai prestasi dengan bentuk kurva normal. Saran untuk penelitian selanjutnya adalah perlunya studi ekperimen kemampuan baca mahasiswa terhadap sumber informasi yang digunakan.
\end{abstract}

Kata Kunci: Prestasi akademik mahasiswa; Akses sumber informasi; Sumber informasi multi akses

\section{ABSTRACT}

Introduction. In the process of reading, students require different information sources to increase their academic achievement. This paper aims to examine information sources which have a relationship with students academic achievement and become a reference in the development of information sources to support student academic achievement.

Method. The research used an experimental study, with $N=38$. Based on the value of chi-square of 11,613, a Pvalue of 0.169 with $\alpha=0.25 ; d f=8$, and the chi-quadrat table $=10.2$. It showed that chi-quadrat count (11.6) is more than chi-quadrat table (10.2). If chi-quadrat counts more than chi-quadrat table, the student academic achievement has a significant relationship with access to information sources.

Results and Discussions. The results showed that students' academic achievements have a significant relationship with access to information sources. The behavior of students in accessing information sources had moderate degrees of relationship with their academic achievement, which means that there is no dominant information source used by the students related to their academic achievement.

Conclusion. In this study, students prefer to choose multi-acsess information resources, resulting in the spread of the values of the normal curve to the shape of academic achievements. Further research should discuss students' reading ability towards the use of information sources.

Keywords: Student academic achievement; Access resources; Sources of information multipleaccess 


\section{A. PENDAHULUAN}

Kegiatan membaca merupakan aktivitas artifisial, yakni aktivitas yang dipelajari dan berlangsung terus-menerus sehingga dapat meningkatkan minat baca seseorang. Minat baca diartikan sebagai kecenderungan hati yang tinggi pada suatu sumber bacaan terlebih lagi bagi mahasiswa guna meningkatkan aktivitas membaca terhadap buku teks (Riyan, Prijana, \& Sukaesih, 2015). Membaca merupakan satusatunya cara dalam melatih kemampuan mencerna teks di mana semakin banyak seseorang melakukan aktivitas membaca, semakin terbiasa pula seseorang tersebut memahami bahan bacaan yang kompleks, yang pada akhirnya aktivitas tersebut akan menjadikannya sebagai pembaca yang lebih baik (Anugrah, 2017).

Gagasan mengenai membaca (reading) yang dikemukakan Adler \& Doren (1972) dalam karya bukunya yang berjudul How to read a book pernah menggemparkan Eropa yang memberikan gagasan yang menjadikan masyarakat Eropa menjadi literat. Gagasan tersebut juga memberikan inspirasi bagi Frank Hatt (1986) untuk menerbitkan karya terkait membaca yang berjudul The Reading Process yang secara eksplisit mencoba memahami apa itu membaca, who is the reader? Hatt (1986) menegaskan bahwa the reader is a literate person yang selanjutnya oleh Hatt menyatakan konsep tentang reading is tools.

Berbagai penelitian yang dilakukan menunjukkan bahwa mahasiswa memiliki keterampilan yang berbeda dalam membaca, hal ini ditunjukkan dari mahasiswa yang memiliki prestasi akademik yang lebih tinggi cenderung lebih cepat waktu membacanya dan lebih sering melakukan aktivitas membaca dan memiliki kemampuan good reading. (Prijana \& Rohman, 2017; Prijana \& Yanto, 2016).

Pada kenyataannya, para mahasiswa dalam proses membaca memerlukan berbagai informasi dengan melakukan berbagai proses pencarian informasi melalui berbagai titik akses guna memenuhi kebutuhan aktivitas akademiknya ataupun minat dari mahasiswa tersebut. Seperti yang dinyatakan Ready \& Rumyeni, (2016) bahwa kebutuhan informasi mahasiswa dalam akses sumber informasi juga dapat dikaitkan dengan perkuliahan ataupun minat pribadi. Selain itu menurut Wijaya (2012) berdasarkan hasil penelitian menunjukkan bahwa prestasi akademik mahasiswa memiliki pengaruh signifikan dari kegiatan penggunaan internet.

Oleh sebab itu, peneliti tertarik melakukan penelitian tentang prestasi akademik mahasiswa yang dikaitkan dengan akses sumber informasi. Tujuan penelitian ini untuk mengetahui apakah prestasi akademik mahasiswa memiliki hubungan signifikan dengan akses sumber informasi. Adapun hipotesis untuk menjawab pertanyaan penelitian tersebut adalah $\mathrm{H}_{0}$ : Prestasi akademik mahasiswa memiliki hubungan non-signifikan dengan akses; $\mathrm{H}_{1}$ : Prestasi akademik mahasiswa memiliki hubungan signifikan dengan akses sumber informasi. Penelitian ini diharapakan dapat memberikan temuan terkait sumber informasi manakah yang memiliki hubungan dengan prestasi akademik mahasiswa, sehingga dapat memberikan pertimbangan dalam pengembangan sumber informasi mana saja yang dapat mendukung peningkatan prestasi akademik mahasiswa terkait akses sumber informasi.

\section{B. TINJAUAN PUSTAKA}

Menurut Rahim (2008) terdapat 3 keterampilan dasar dalam membaca yaitu recording, decoding, dan meaning. Recording merujuk pada kata-kata dan kalimat yang diasosiasikan dengan bunyi-bunyinya sesuai dengan sistem tulisan. Adapun proses decoding merujuk pada proses penerjemahan rangkaian grafis ke dalam kata-kata. Sedangkan meaning merujuk pada proses memahami makna yang berlangsung dari tingkat pemahaman, pemahaman interpretatif, kreatif, dan evaluatif. Proses recording dan decoding berlangsung pada siswa kelas dasar, sedangkan meaning lebih ditekankan pada kelas tinggi.

Kegiatan membaca dalam dunia akademik seharusnya banyak dilakukan di lembaga informasi seperti perpustakaan sebagai pusat informasi guna membantu menyediakan berbagai sumber daya informasi untuk proses 
pembelajaran. Salah satu tujuan akhir dari penyediaan layanan tersebut adalah meningkatkan prestasi akademik. Berdasarkan kajian yang dilakukan oleh Merliana (2015) dinyatakan bahwa terdapat hubungan antara fungsi fasilitas perpustakaan dengan peningkatan kinerja akademik mahasiswa berdasarkan kunjungan ke perpustakaan. Selanjutnya berdasarkan hasil penelitian yang dilakukan Ginasari, Burhanuddin dan Wiyanto (2016) menunjukkan adanya hubungan yang signifikan antara layanan perpustakaan dan minat baca dengan prestasi belajar mahasiswa.

Berbagai eksperimen telah dilakukan terkait dengan aktivitas membaca. Adapun kajian Lestari, Nupikso dan Riyani (2015) menunjukkan bahwa penggunaan bahan ajar online yang terdapat pada tutorial online memiliki pengaruh positif terhadap peningkatan prestasi mahasiswa. Dengan demikian, intensitas penggunaan bahan ajar online harus lebih ditingkatkan, meliputi alat yang secara fisik digunakan untuk menyampaikan isi materi.

Hasil studi eksperimen yang dilakukan Prijana \& Rohman (2017) mengatakan bahwa mahasiswa memiliki keterampilan dan keterlatihan membaca yang berbeda satu sama lainnya. Mereka memiliki kecepatan waktu baca yang berbeda satu sama lainnya. Mereka yang memiliki prestasi akademik lebih tinggi memiliki kecenderungan lebih cepat waktu bacanya dibandingkan dengan yang memiliki prestasi akademik lebih rendah. Mereka yang memiliki prestasi akademik lebih tinggi, memiliki kebiasaan membaca yang juga berbeda dengan yang memiliki prestasi lebih rendah. Mereka yang memiliki prestasi akademik lebih tinggi, sering melakukan aktivitas membaca dibandingkan dengan yang memiliki prestasi akademik lebih rendah. Disini tingkat keseringan membaca diartikan sebagai keterlatihan. Sehingga dapat dikatakan bahwa semakin terlatih membaca, semakin cepat waktu bacanya.

Menurut Warsito (2009) prestasi akademik ditandai dengan nilai-nilai optimal yang diperoleh dengan indikator IP (Indeks Prestasi) maupun IPK (Indeks Prestasi Kumulatif) serta ketepatan waktu dalam menyelesaikan studi sebagai bagian dari hasil penyesuaian diri mahasiswa dalam proses pembelajaran. Prestasi akademik mahasiswa yang memiliki IPK lebih tinggi dan memiliki kemampuan baca yang lebih baik serta memiliki kemampuan mejawab berbagai soal ujian lebih baik.

Prijana \& Sukaesih (2016) dalam studi eksperimennya juga menunjukkan bahwa kemampuan menjawab soal multiplechoice memiliki hubungan signifikan dengan metode baca good reading. Kemampuan mahasiswa dalam menjawab soal memiliki hubungan signifikan dengan metode baca good reading dengan derajat kepercayaan $90 \%$.

Selanjutnya, Prijana \& Yanto (2016) dalam studi eksperimennya lainnya menunjukkan bahwa prestasi akademik mahasiswa memiliki hubungan signifikan dengan metode baca good reading. Disini prestasi akademik mahasiswa memiliki hubungan korelasi signifikan dengan metode baca good reading, jika derajat kepercayaan $99 \%$.

Lebih lanjut Prijana, Komariah \& Rohman (2016) melakukan analisis kontingensi terhadap hubungan prestasi akademik menurut gender. Sebelumnya, orang memandang mitos atau fakta bahwa mahasiswa perempuan memiliki keunggulan akademik dibandingkan laki-laki. Kali ini ditemukan ada fakta bahwa jenis kelamin menentukan prestasi akademik mahasiswa. Penelitian dapat dilanjutkan dengan adanya fenomena menarik bahwa prestasi akademik mahasiswa memiliki sebaran nilai yang ekstrem, yakni dari nilai yang tinggi sampai dengan nilai yang rendah. Sementara umumnya mereka memiliki kontrak jumlah SKS yang sama, yakni 24 SKS atau dapat dikatakan bahwa mereka memiliki rentang IPK (IPK 3.00-4.00).

\section{METODE PENELITIAN}

Penggunaan metode penelitian kuantitatif post positivis menjadi dasar dalam penelitian ini. Metode post positivis bersifat kausalitatif, yakni memiliki hubungan sebab-akibat, tunduk pada ruang dan waktu. Metode post positivis berbasiskan data (sense datum) dan melakukan verifikasi, yakni pengujian hipotesis. dalam post positivis lebih menekankan pada verifikasi data 
dan penggunaan metode analisis statistik tampak lebih menonjol. (Prijana, Winoto \& Yanto, 2016).

Populasi ( $\mathrm{N}=38$ ) adalah mahasiswa semester 3 (tiga) pada Program Studi Ilmu Perpustakaan yang ada di Fakultas Ilmu Komunikasi, Universitas Padjadjaran. Mereka setelah pertemuan ke 7 (tujuh) tatap muka kelas, dan pada pertemuan ke 8 (delapan) dilakukan ujian tengah semester. Pada pertemuan ke 1 (satu) sampai dengan ke 7 (tujuh) mereka memperoleh materi kuliah sesuai RPS/SAP/GBPP dan beberapa literatur yang digunakan dalam matakuliah/perkuliahan. Mereka juga sudah mengetahui $\mathrm{H}-7$ sebelum adanya ujian semester. Sumber-sumber informasi juga sudah disampaikan misalnya dari sumber koleksi pribadi, seperti buku milik pribadi, buku fotocopy, catatan kuliah atau dari sumber koleksi perpustakaan.

Soal ujian (instrumen penelitian) dalam bentuk multiplechoice dan diberikan waktu 60 menit untuk mengerjakan soal. Nilai ujian di sini dimaksudkan sebagai prestasi akademik mahasiswa. Selanjutnya, metode analisis data menggunakan statistika deskriptif, yakni melakukan analisis hubungan asosiasi Chikuadrat, dengan menentukan signifikansinya. Hasil yang dilakukan terhadap data yang telah diperoleh menggunakan analisis Chi-Square dalam prosesnya juga membutuhkan sebuah tabel atau yang dinamakan tabel kontingensi (Prijana, Winoto \& Yanto, 2016). Jika masih dirasa belum memuaskan, maka akan dilanjutkan dengan mencari koefisien kontingensi $\mathrm{C}$ untuk maksud mengetahui keeratan hubungan asosiasinya (Sudjana, 2016).

\section{HASIL DAN PEMBAHASAN}

Berdasarkan data penelitian yang diperoleh dengan $\mathrm{N}=38$ diperoleh tabel kontingensi yang dapat dilihat pada Tabel 1 sampai Tabel 3.

B erdasarkan Tabel 1, terdapat kecenderungan mereka yang memiliki akses terhadap sumber informasi multi akses yang memiliki prestasi akademik tinggi, yang didominasi nilai prestasi A dan B. Sementara mahasiswa yang memiliki akses sumber informasi koleksi pribadi memiliki prestasi akademik dengan sebarannya relatif merata dari nilai prestasi tertinggi sampai rendah, walau ada kecenderung masih memiliki prestasi yang cukup tinggi. Untuk mahasiswa yang memiliki akses sumber informasi perpustakaan memiliki prestasi akademik yang ekstrem yang cenderung menuju pada prestasi tinggi. Jika dilihat dari peminatan terhadap akses sumber informasi, maka akses multi akses menempati posisi tertinggi, disusul dengan akses koleksi pribadi, dan yang masih relatif kurang peminatan adalah akses sumber koleksi perpustakaan. Hampir separuh mahasiswa yang suka terhadap sumber informasi yang dimiliki perpustakaan, walau sumber koleksi pribadi lebih untuk dipilih. Faktor keterbatasan waktu pinjam merupakan alasan mereka untuk menggunakan sumber informasi perpustakaan. Mereka cenderung menginginkan waktu yang longgar dalam mengakses sumber informasi dibandingkan dengan waktu yang dikontrol oleh aturan kelembagaan.

Berdasarkan Tabel 2, terdapat kecenderungan yang memiliki nilai atau prestasi akademik yang baik menggunakan teknik multi akses dalam akses pada sebuah informasi. Sebaliknya mahasiswa yang memiliki prestasi akademik rendah yang ditunjukkan dengan nilai D dan E hanya melakukan akses informasi pada koleksi probadi yang mereka miliki. Dengan kata lain, terdapat keterkaitan tinggi rendahnya prestasi mahasiswa terhadap pemilihan akses informasi, hal ini terlihat bahwa mahasiswa yang memiliki prestasi yang baik mampu melakukan pencarian informasi melalui multi akses baik menggunakan koleksi perpustakaan maupun koleksi yang dimiliki sendiri/pribadi. Keterbatasan masing-masing sumber informasi, baik itu koleksi pribadi maupun koleksi perpustakaan mengantarkan mereka untuk memilih akses sumber informasi kombinasi, yakni multi akses sumber informasi sebagai pilihan yang diminati. Kali ini juga terdapat hal yang menarik untuk disimak seperti yang ditunjukkan tabel, bahwa mereka yang memilih akses sumber informasi koleksi perpustakaan memiliki prestasi akademik yang cenderung lebih baik dibandingkan dengan mereka yang menggunakan akses sumber informasi koleksi 
pribadi, walau akses sumber informasi multi akses masih merupakan pilihan tertinggi mahasiswa atau paling diminati.

Berdasarkan Tabel 3 di atas terlihat nilai chisquare hitung sebesar 11.613, dengan P-value sebesar 0,169 , jika $\alpha=0.25$; dk $=8$, maka Chiquadrat tabel $=10.2$; artinya Chi-quadrat hitung (11.6) lebih besar daripada Chi-quadrat tabel (10.2) ; Jika Chi-quadrat hitung lebih besar daripada Chi-quadrat tabel, maka prestasi akademik mahasiswa memiliki hubungan signifikan dengan akses sumber informasi. Hipotesis: diterima. Kesimpulan: Dengan derajat kepercayaan $75 \%$ prestasi akademik mahasiswa memiliki hubungan significant dengan akses sumber informasi.

Jika $\alpha=0.10 ; \mathrm{dk}=8$, maka Chi-quadrat tabel (13.4); artinya Chi-quadrat hitung (11.6) lebih kecil daripada Chi-quadrat tabel (13.4); Jika Chi-quadrat hitung lebih kecil daripada Chiquadrat tabel maka prestasi akademik memiliki hubungan non- signifikan dengan akses sumber informasi. Hipotesis: ditolak. Kesimpulan: Dengan derajat kepercayaan $90 \%$ prestasi akademik mahasiswa tidak memiliki hubungan signifikan dengan akses sumber informasi. Disini peneliti cukup bimbang untuk mengambil kesimpulan.

Berdasarkan analisis data, dengan derajat kepercayaan 75\%, maka prestasi akademik mahasiswa memiliki keterkaitan dengan akses sumber informasi, artinya akses terhadap sumber informasi memiliki keterkaitan dengan prestasi akademik. Mereka yang menggunakan multi akses sumber informasi (Akses koleksi perpustakaan, akses koleksi pribadi, e-book ) memiliki peluang terhadap prestasi akademik tinggi. Namun jika derajat kepercayaan ditingkatkan menjadi $90 \%$, maka prestasi akademik memiliki hubungan non-signifikan dengan akses sumber informasi.

Karena itu peneliti melanjutkan dengan upaya statistik untuk maksud memperoleh keyakinan hubungan antar variabel. Seiring dengan ingin kita ketahuinya derajat keeratan hubungan asosiasi mengenai prestasi akademik mahasiswa dengan akses sumber informasi, dimana kita ketahui Chi-kuadrat hitung(11.6) dan $(\mathrm{N}=38)$; maka dapat kita cari koefisien kontingensi-nya sebagai berikut:

$$
\begin{aligned}
C & =\sqrt{ } \frac{11.6}{11.6+38} \\
& =0.48
\end{aligned}
$$

Supaya nilai $\mathrm{C}$ yang diperoleh dapat digunakan dalam menghitung derajat asosiasi antara prestasi akademik mahasiswa dengan akses sumber informasi, maka harga $\mathrm{C}$ ini akan dibandingkan dengan koefisien maksimum yang bisa terjadi, dengan harga $\mathrm{C}_{\text {maksimum }}$ sebagai berikut:

$$
\begin{aligned}
& \mathrm{C}_{\text {Maks }}=\frac{\sqrt{(3-1)}}{3} \\
& =0.816
\end{aligned}
$$

Asumsi: semakin dekat harga $\mathrm{C}$ kepada $\mathrm{C}_{\text {Maks }}$ semakin besar pula derajat asosiasi antara prestasi akademik dengan akses sumber informasi. Membandingkan harga $\mathrm{C}=0.48$ dengan harga $\mathrm{C}_{\text {Maks }}=0.816$ tampak bahwa variabel prestasi akademik mahasiswa dengan variabel akses sumber informasi memiliki derajat hubungan asosiasi moderat.

Jika dicermati dari sebaran nilai prestasi akademik mahasiswa, menunjuk pada kurva normal, artinya nilai-nilai prestasi akademik terdistribusi memuaskan, atau dapat dikatakan pada kisaran $80 \%$ nilai-nilai prestasi akademik berada pada posisi memuaskan. Sementara hanya pada kisaran $20 \%$ nilai-nilai prestasi akademik berada pada posisi tidak memuaskan. Di sini prestasi akademik mahasiswa dapat dikatakan memiliki keterkaitan dengan akses sumber informasi. Persoalannya, akses sumber informasi yang mana yang memiliki keterkaitan paling dekat dengan prestasi akademik.

Jika dicermati dari akses sumber informasi, diketahui bahwa mahasiswa mengakses sumber informasi pribadi, dan mengakses sumber informasi perpustakaan, atau kedua-duanya yang dinamakan multi akses. Selanjutnya, jika dibandingkan antara akses sumber informasi pribadi dengan akses sumber informasi perpustakaan, maka sebagian menggunakan sumber informasi pribadi, seperti sumber informasi catatan kuliah. Sebagian lagi 
menggunakan sumber informasi buku koleksi perpustakaan. Namun sebagian besar menggunakan sumber informasi multi akses, dan mereka yang menggunakan sumber informasi multi akses memiliki jumlah tertinggi, artinya mahasiswa memiliki kecenderungan untuk memilih akses sumber informasi secara multi akses.

\section{E. KESIMPULAN}

Perilaku mahasiswa dengan mengakses sumber informasi multi akses memiliki derajat hubungan moderat dengan prestasi akademik yang dicapai, artinya tidak ada sumber informasi yang dominan yang dipakai mahasiswa dalam rangka meraih prestasi akademik. Sumber informasi buku koleksi perpustakaan bukan merupakan sumber informasi utama yang diakses mahasiswa. Mahasiswa lebih memilih untuk mengakses sumber informasi multi akses, yang menghasilkan sebaran nilai prestasi dengan bentuk kurva normal, atau dapat dikatakan bahwa sebaran nilai prestasi mencapai ideal.

\section{DAFTAR PUSTAKA}

Adler, M. J. \& Doren, C. V. (1972). How to read a book: The classic guide to intelligent reading. New York: Simon \& Schuster.

Anugrah, D. (2017, April 13). Membaca menentukan masa depan. Https://tirto.id. Retrieved from https://tirto.id/membacamenentukan-masa-depan-cmCf

Ginasari, O., Buhanuddin \& Wiyanto, T. T. (2016). Hubungan layanan perpustakaan dan minat baca dengan prestasi belajar mahasiswa Jurusan Administrasi Pendidikan Fakultas Ilmu Pendidikan Universitas Negeri Malang. SKRIPSI: Jurusan Administrasi Pendidikan-Fakultas Ilmu Pendidikan UM.

Hatt, F. (1986). The reading process: $A$ framework for analysis and description. London: Clive Bingley.

Lestari, E., Nupikso, G., \& Riyani, E. (2015). Pengaruh penggunaan bahan ajar online terhadap prestasi mahasiswa Universitas Terbuka. Jurnal Pendidikan Terbuka Dan JarakJauh, 16(1), 1-9.
Merliana, N. P. E. (2015). Perbandingan metode $K$-Means dengan fuzzy C-Means untuk analisa karakteristik mahasiswa berdasarkan kunjungan ke perpustakaan (Studi kasus Sekolah Tinggi Agama Hindu Negeri Tampung Penyang Palangka Raya). S2 Thesis: UAJY.

Prijana, Winoto, Y., \& Yanto, A. (2016). Metode penelitian kuantitatif Ilmu Perpustakaan dan Informasi. Bandung: Unpad Press.

Prijana, \& Yanto, A. (2016). Uji korelasi tentang prestasi akademik dengan metode baca mahasiswa (Studi eksperimen tentang metode bacateks ilmu pengetahuan). In Prosiding : Akselersi Pembangunan Masyarakat Lokal Melalui Komunikasi Dan Teknologi Informasi (Buku 1) (pp. 383386). Bandar Lampung. Retrieved from http://jurnal.fisip.unila.ac.id/index.php/pro sidingkom/article/view/253

Prijana \& Sukaesih (2016). The relations of students ability to read throught the good reading method with their ability to answer the multiplechoice questions. Edulib, 6(2), 129-137.

Prijana, P., \& Rohman, A. (2017). Studi eksperimen mengenai metode baca good reading. Lentera Pustaka, 2(2), 71-81.

Prijana, Komariah, N., \& Asep S. Rahman (2016). Analisis kontingensi: Prestasi akademik mahasiswa Program Studi Ilmu Perpustakaan menurut gender. Jurnal Palimpsest, 8(1), 40-47.

Rahim, F. (2008). Pengajaran membaca di sekolah dasar. Jakarta: Bumi Aksara.

Ready, A. \& Rumyeni. (2016). Penggunaan media online sebagai sumber informasi akademik mahasiswa Ilmu Komunikasi Fakultas Ilmu Sosial dan Ilmu Politik Universitas Riau. Jurnal online mahasiswa Fakultas Ilmu Sosial dan Ilmu Politik Universitas Riau 3(1), 1-15.

Riyan, A., Prijana, P., \& Sukaesih, S. (2015). Potensi membaca buku teks (studi pada mahasiswa program Studi Ilmu Perpustakaan Fakultas Ilmu Komunikasi Universitas Padjadjaran Bandung). Jurnal Kajian Informasi \& Perpustakaan, 3(1), 8188. 
Sudjana. (2016). Metoda statistika. Bandung: Tarsito.

Warsito, Hadi (2009). Hubungan antara selfefficacy dengan penyesuaian akademik dan prestasi akademik (Studi pada mahasiswa FIP Universitas Negeri Surabaya). Pedagogi: Jurnal Ilmu Pendidikan, 9(1), 29-47.
Wijaya, A. L. (2012). Pengaruh penggunaan teknologi informasi terhadap prestasi akademik mahasiswa. Jurnal Pendidikan Akuntansi (JPA), 1(2), 1-13. 


\section{DAFTAR TABEL}

Tabel 1. Hubungan Prestasi Akademik Mahasiswa Dengan Akses Sumber Informasi

\begin{tabular}{ccccccc}
\hline & $\mathrm{E}$ & $\mathrm{D}$ & $\mathrm{C}$ & $\mathrm{B}$ & $\mathrm{A}$ & JUMLAH \\
$(0-44)$ & $(44-55)$ & $(56-67)$ & $(68-79)$ & $(80-100)$ & 6 & 7 \\
\hline AKSES & & & 1 & & 3.868 & \\
BUKU KOLEKSI & 0.184 & 0.552 & 0.552 & 1.657 & 5 & 14 \\
$\begin{array}{c}\text { PERPUSTAKAAN } \\
\text { AKSES BUKU }\end{array}$ & 1 & 3 & 1 & 4 & 7.736 & \\
$\begin{array}{c}\text { KOLEKSI } \\
\text { PRIBADI }\end{array}$ & 0.368 & 1.105 & 1.105 & 3.315 & 11 & \\
$\begin{array}{c}\text { MULTI AKSES } \\
\text { SUMBER } \\
\text { INFORMASI }\end{array}$ & 0.421 & 1.263 & 1.263 & 3.789 & 8.842 & \\
\hline JUMLAH & 1 & 3 & 3 & 9 & 22 & 38 \\
\hline
\end{tabular}

Tabel 2. Analis Crosstabs

\begin{tabular}{|c|c|c|c|c|c|c|c|}
\hline \multicolumn{2}{|c|}{ Akses Informasi } & \multicolumn{5}{|c|}{ Prestasi } & \multirow{2}{*}{ Total } \\
\hline & & $\mathrm{E}$ & $\mathrm{D}$ & $\mathrm{C}$ & B & $\mathrm{A}$ & \\
\hline \multirow{5}{*}{$\begin{array}{l}\text { Akses Koleksi } \\
\text { Perpustakaan }\end{array}$} & Count & 0 & 0 & 1 & 0 & 6 & 7 \\
\hline & Expected Count &, 2 & 6 & 6 & 1,7 & 4,1 & 7,0 \\
\hline & $\begin{array}{l}\% \text { within Akses } \\
\text { Informasi }\end{array}$ & $0,0 \%$ & $0,0 \%$ & $14,3 \%$ & $0,0 \%$ & $85,7 \%$ & $100,0 \%$ \\
\hline & $\%$ within Prestasi & $0,0 \%$ & $0,0 \%$ & $33,3 \%$ & $0,0 \%$ & $27,3 \%$ & $18,4 \%$ \\
\hline & $\%$ of Total & $0,0 \%$ & $0,0 \%$ & $2,6 \%$ & $0,0 \%$ & $15,8 \%$ & $18,4 \%$ \\
\hline \multirow{5}{*}{$\begin{array}{l}\text { Akses Koleksi } \\
\text { Pribadi }\end{array}$} & Count & 1 & 3 & 1 & 4 & 5 & 14 \\
\hline & Expected Count & ,4 & 1,1 & 1,1 & 3,3 & 8,1 & 14,0 \\
\hline & $\begin{array}{l}\% \text { within Akses } \\
\text { Informasi }\end{array}$ & $7,1 \%$ & $21,4 \%$ & $7,1 \%$ & $28,6 \%$ & $35,7 \%$ & $100,0 \%$ \\
\hline & $\%$ within Prestasi & $100,0 \%$ & $100,0 \%$ & $33,3 \%$ & $44,4 \%$ & $22,7 \%$ & $36,8 \%$ \\
\hline & $\%$ of Total & $2,6 \%$ & $7,9 \%$ & $2,6 \%$ & $10,5 \%$ & $13,2 \%$ & $36,8 \%$ \\
\hline \multirow[t]{5}{*}{ Multi Akses } & Count & 0 & 0 & 1 & 5 & 11 & 17 \\
\hline & Expected Count & ,4 & 1,3 & 1,3 & 4,0 & 9,8 & 17,0 \\
\hline & $\begin{array}{l}\% \text { within Akses } \\
\text { Informasi }\end{array}$ & $0,0 \%$ & $0,0 \%$ & $5,9 \%$ & $29,4 \%$ & $64,7 \%$ & $100,0 \%$ \\
\hline & \% within Prestasi & $0,0 \%$ & $0,0 \%$ & $33,3 \%$ & $55,6 \%$ & $50,0 \%$ & $44,7 \%$ \\
\hline & $\%$ of Total & $0,0 \%$ & $0,0 \%$ & $2,6 \%$ & $13,2 \%$ & $28,9 \%$ & $44,7 \%$ \\
\hline \multirow[t]{3}{*}{ Total } & Count & 1 & 3 & 3 & 9 & 22 & 38 \\
\hline & Expected Count & 1,0 & 3,0 & 3,0 & 9,0 & 22,0 & 38,0 \\
\hline & $\%$ within Prestasi & $100,0 \%$ & $100,0 \%$ & $100,0 \%$ & $100,0 \%$ & $100,0 \%$ & $100,0 \%$ \\
\hline
\end{tabular}

Tabel 3. Chi-Square Test Hubungan Akses Informasi dengan Prestasi Akademik

\begin{tabular}{lccr}
\hline & Value & df & \multicolumn{2}{c}{$\begin{array}{c}\text { Asymp. Sig. } \\
\text { (2-sided) }\end{array}$} \\
\hline Pearson Chi-Square & $11,613^{\text {a }}$ & 8 &, 169 \\
Likelihood Ratio & 14,377 & 8 &, 072 \\
Linear-by-Linear &, 224 & 1 &, 636 \\
Association & 38 & & \\
N of Valid Cases & 38 & & \\
\hline
\end{tabular}

